\title{
Assessing the trends and effects of environmental parameters on the behaviour of mercury in the lower atmosphere over cropped land over four seasons
}

\author{
A. P. Baya and B. Van Heyst \\ School of Engineering, University of Guelph, Guelph, ON, Canada \\ Received: 1 December 2009 - Published in Atmos. Chem. Phys. Discuss.: 3 February 2010 \\ Revised: 19 July 2010 - Accepted: 2 August 2010 - Published: 15 September 2010
}

\begin{abstract}
Mercury is released to the atmosphere from natural and anthropogenic sources. Due to its persistence in the atmosphere, mercury is subject to long range transport and is thus a pollutant of global concern. Mercury emitted to the atmosphere enters terrestrial and aquatic ecosystems which act as sinks but also as sources of previously emitted and deposited mercury when the accumulated mercury is emitted back to the atmosphere. Studying the factors and processes that influence the behaviour of mercury from terrestrial sources is thus important for a better understanding of the role of natural ecosystems in the mercury cycling and emission budget.

A study was conducted over ten months (November 2006 to August 2007) at Elora, Ontario, Canada to measure gaseous elemental mercury (GEM), reactive gaseous mercury (RGM) and particulate bound mercury $\left(\mathrm{Hg}^{\mathrm{P}}\right)$ as well as GEM fluxes over different ground cover spanning the four seasons typical of a temperate climate zone. GEM concentrations were measured using a mercury vapour analyzer (Tekran 2537A) while RGM and $\mathrm{Hg}^{\mathrm{P}}$ were measured with the Tekran 1130/1135 speciation unit coupled to another mercury vapour analyzer. A micrometeorological approach was used for GEM flux determination using a continuous two-level sampling system for GEM concentration gradient measurement above the soil surface and crop canopy. The turbulent transfer coefficients were derived from meteorological parameters measured on site.
\end{abstract}

A net GEM volatilization $\left(6.31 \pm 33.98 \mathrm{ng} \mathrm{m}^{-2} \mathrm{hr}^{-1}\right.$, study average) to the atmosphere was observed. Average GEM concentrations and GEM fluxes showed significant

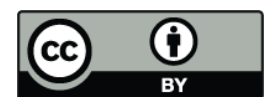

Correspondence to: A. P. Baya (anabellebaya@gmail.com) seasonal differences and distinct diurnal patterns while no trends were observed for $\mathrm{Hg}^{\mathrm{P}}$ or RGM. Highest GEM concentrations, recorded in late spring and fall, were due to meteorological changes such as increases in net radiation and air temperature in spring and lower atmospheric mixing height in fall. Highest GEM fluxes (18.1 $\mathrm{ng} \mathrm{m}^{-2} \mathrm{hr}^{-1}$, monthly average) were recorded in late spring but also during specific events in winter and fall. The main factors influencing the GEM flux were soil moisture content, soil temperature, precipitation events and ground cover. These trends indicate that the soil surface could be a significant mercury source in spring and summer seasons but also under specific meteorological conditions during the winter and fall.

\section{Introduction}

Mercury is a priority pollutant due of its ability to accumulate in the food chain in the form of methylmercury, a neurotoxin to living organisms and human beings (Satoh, 2000). Mercury is also a global persistent pollutant, as once released, mercury in its elemental form $\left(\mathrm{Hg}^{0}\right)$, remains in the atmosphere for up to 1 year (Lindberg et al., 2007) and can be transported over regional and global distances.

Most of the mercury in the atmosphere (>95\%) is in the gaseous form (Iverfeldt and Lindqvist, 1986; Munthe, 1992; Gustin, 2003) and exists in three oxidation states; $0,+1$ and +2 . However, in the atmospheric environment, mercury exists predominantly in the elemental form $\mathrm{Hg}^{0}$ referred to as gaseous elemental mercury (GEM) and in the +2 oxidation state $\mathrm{Hg}^{2+}$ referred to as reactive gaseous mercury (RGM) such as $\mathrm{HgCl}_{2}$ or $\mathrm{HgBr}_{2}$ (Schroeder and Munthe, 1998). Another important form of mercury in the atmosphere

Published by Copernicus Publications on behalf of the European Geosciences Union. 


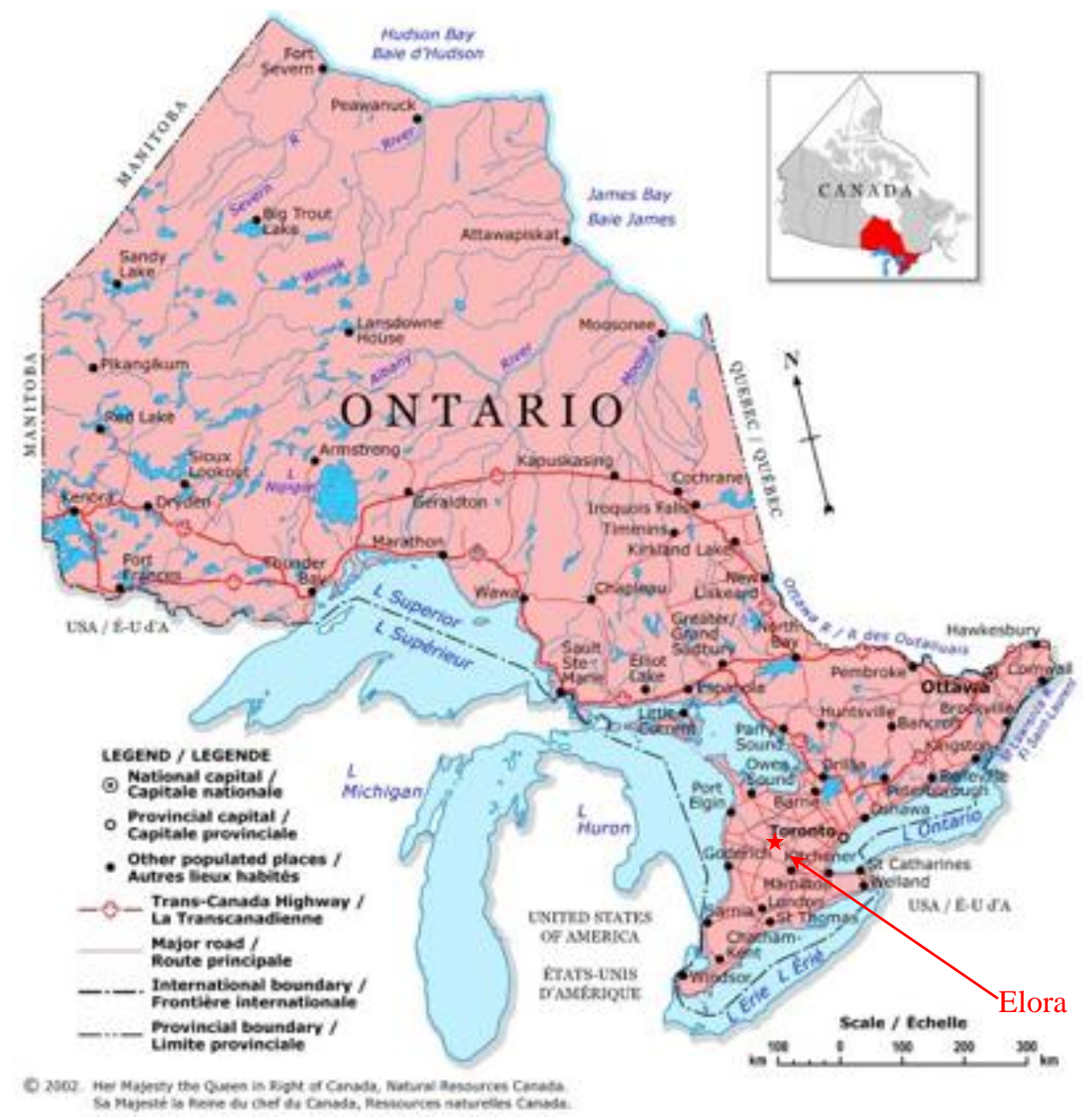

Fig. 1. Geographical location of research study site in Elora, ON, Canada.

is particulate bound mercury $\left(\mathrm{Hg}^{\mathrm{P}}\right)$. It is present in the atmosphere either from anthropogenic sources (Schroeder and Munthe, 1998) or from GEM or RGM adsorbed onto particle matter (PM) in the atmosphere (Schroeder and Munthe, 1998; Seigneur et al., 2004). Mercury is vertically well mixed in the troposphere and typical GEM concentrations are in the range of $1-4 \mathrm{ng} \mathrm{m}^{-3}$ at background sites (Iverfeldt and Lindqvist, 1986; Lin and Pehkonen, 1999). In contrast, background RGM and $\mathrm{Hg}^{\mathrm{P}}$ concentrations range between $5-70 \mathrm{pg} \mathrm{m}^{-3}$ and $7-100 \mathrm{pg} \mathrm{m}^{-3}$ respectively (Valente et al., 2007) representing less than $5 \%$ of atmospheric mercury.

Global $\mathrm{Hg}$ cycling models estimate that anywhere from $50 \%$ to $70 \%$ of mercury in the atmosphere is deposited, via dry and wet deposition, onto land surfaces (Lindberg et al., 2007; Mason and Sheu, 2002; Mason et al., 1994). These same land surfaces have been estimated to re-emit anywhere from $14 \%$ to $24 \%$ of the total atmospheric burden (Mason and Sheu, 2002; Mason et al., 1994) thus making land surfaces an important atmospheric mercury sink (Fitzgerald, 1995; Mason et al., 1994). The deposited Hg is a combination of newly emitted anthropogenic $\mathrm{Hg}$ along with previ- ously emitted $\mathrm{Hg}$ that cycles between different environmental compartments.

In natural terrestrial ecosystems, the behaviour and cycle of $\mathrm{Hg}$ at the soil and atmosphere interface is believed to be controlled by the soil properties, biological processes, meteorological conditions and atmospheric chemistry and physics. In addition, the presence of a vegetation canopy will also affect the behaviour of $\mathrm{Hg}$ either being deposited from the atmosphere or being emitted from the soil. It is thus important not only to understand how $\mathrm{Hg}$ behaves over these landscapes but also to try to quantify the contribution of terrestrial land sources to the $\mathrm{Hg}$ emission cycle and budget.

Recent technological and analytical developments now enable high time resolution measurements of atmospheric GEM concentrations necessary to determine GEM fluxes using micrometeorological methods (Edwards et al., 2005; Cobbett and Van Heyst, 2007; Cobbett et al., 2007; Lindberg and Meyers, 2001; Zhang et al., 2001; Poissant et al., 1999) and flux chamber methods (Gustin et al., 1997; Engle et al., 2001). GEM flux measurement studies attempt to identify the main factors controlling the emissions and deposition 
of mercury from different surfaces. GEM flux studies conducted in the field are typically short in duration spanning up to a couple months (for example, Cobos et al., 2002; Cobbett and Van Heyst, 2007). A few studies have spanned periods of up to a year looking at GEM fluxes above controlled tallgrass praire monoliths (Obrist et al., 2005) and European sub-alpine grasslands (Fritsche et al., 2008) but represent a limited number of terrestrial surfaces. These longer study periods are essential to assess the impacts of seasonality and changing environmental conditions on the behaviour of the GEM flux data.

With the advent of the Tekran 1130/1135 Hg speciation units for RGM and $\mathrm{Hg}^{\mathrm{P}}$, respectively, numerous studies have focused on measuring the concentrations of GEM, RGM and $\mathrm{Hg}^{\mathrm{P}}$ above various terrestrial surfaces (see Table 1 for a summary of studies over rural landscapes) to better understand the cycling of $\mathrm{Hg}$ between its different atmospheric forms. Cobbett and Van Heyst (2007) appears to be the only study that has coupled both the GEM flux measurements with collocated measurements of GEM, RGM and $\mathrm{Hg}^{\mathrm{P}}$ concentrations over bare soil for a more complete understanding of $\mathrm{Hg}$ above a terrestrial surface.

Longer-term GEM flux and GEM, RGM and $\mathrm{Hg}^{\mathrm{P}}$ concentration measurements above varying terrestrial surfaces are needed to better understand the $\mathrm{Hg}$ cycle and calculate the mass balance for $\mathrm{Hg}$. In addition, the longer-term studies can provide a more complete picture of the biogeochemical cycle of $\mathrm{Hg}$ in the environment including the interactions between environmental parameters (e.g. soil moisture, soil temperature, radiation), chemical factors and surface characteristics (e.g. snow or crop cover).

To address theses issues, a study was conducted in Elora, ON, Canada for 10 a month period (fall 2006 to summer 2007) measuring GEM flux as well as atmospheric concentrations of GEM, RGM and $\mathrm{Hg}^{\mathrm{P}}$. The main objective was to assess the seasonal behaviour of the main $\mathrm{Hg}$ species and to quantify the seasonal flux of elemental mercury over different agricultural ground covers.

\section{Methodology}

\subsection{Site location}

The study was conducted from 1 November 2006 to $13 \mathrm{Au}$ gust 2007 (day 305 of 2006 to day 225 of 2007) at the Elora Research Station of the University of Guelph, located $7.5 \mathrm{~km}$ south of Elora, Ontario $\left(43^{\circ} 39^{\prime} \mathrm{N}\right.$ and $\left.80^{\circ} 25^{\prime} \mathrm{W}\right)$ at an elevation of $376 \mathrm{~m}$ (Fig. 1). While the site is considered rural, there are several cities with industrial areas that may influence the site including the city of Kitchener/Waterloo located $30 \mathrm{~km}$ southwest, the city of Stratford situated $75 \mathrm{~km}$ southwest and the city of Hamilton, a major industrial area in the region, situated $70 \mathrm{~km}$ southeast of the study site.
The experimental site was located on a 6 ha plot on an agricultural research station. The crop rotation consisted of soybeans and corn for the 2006 and 2007 cropping season respectively. The only agricultural work during the study involved herbicide application prior to sowing (19 April 2007), manure application (2 May 2007) a few days before fertilizer and sowing (8 May 2007). The plot was left bare during the winter season with half the plot tilled while the other half was non-tilled.

Soil samples were collected prior (July 2006) and after the study (August 2007) as well as after the snow melt (May 2007) by making 2 diagonal transects each with 3 sampling points each across the field while avoiding the edges of the field. The soil, at each sampling location, was sampled to a depth of $5 \mathrm{~cm}$. The soil texture was a silty loam with an average $\mathrm{pH}$ of 7.7 , organic matter $(\mathrm{OM})$ content of $4.2 \%$ dry, and a total carbon content of $2.6 \%$ dry. The total soil mercury concentration was determined by acid digestion and cold vapor atomic absorption spectrophotometry (CV-AAS) yielding an average mercury concentration in the top soil of $0.050 \pm 0.006 \mu \mathrm{g} \mathrm{g}^{-1}$. Variation in the total soil mercury concentration was not significant for the three periods sampled.

\subsection{Aerodynamic micrometeorological gradient method}

The GEM flux was estimated by measuring the difference in GEM concentrations at two different heights above the soil surface or canopy height based on the aerodynamic micrometeorological gradient method (Edwards et al., 2005; Cobbett and Van Heyst, 2007; Cobbett et al., 2007). The aerodynamic micrometeorological gradient method uses the assumption of Monin-Obukhov (MO) similarity and estimates the flux by:

$F=-K \frac{\partial C}{\partial z} \approx \frac{u_{*} \kappa\left(C_{2}-C_{1}\right)}{\ln \left[\frac{z_{2}-d}{z_{1}-d}\right]-\Psi_{h 2}+\Psi_{h 1}}$

where $F$ is the GEM flux (ng m $\left.{ }^{-2} \mathrm{hr}^{-1}\right), K$ is the eddy diffusivity $\left(\mathrm{m}^{2} \mathrm{~s}^{-1}\right)$ and $\partial c / \partial z$ is the concentration gradient of mercury $\left(\mathrm{ng} \mathrm{m}^{-3}\right), u_{*}$ is the surface friction velocity $\left(\mathrm{m} \mathrm{s}^{-1}\right)$, $\kappa$ is von Karman's constant (0.4) (unitless), $z_{2}$ and $z_{1}$ are the upper and lower intake heights respectively $(\mathrm{m}), d$ is the zero plane displacement height (m), and $\Psi_{h 2}$ and $\Psi_{h 1}$ are the integrated stability functions for heat at $z_{2}$ and $z_{1}$ respectively. As the eddy diffusivity varies with height, surface roughness and atmospheric stability state, it needs to be measured concurrently with the gradient (Edwards et al., 2005).

To capture the extensive meteorological parameters required for the gradient method, the study site was equipped with an instrumented $8.5 \mathrm{~m}$ meteorological tower located approximately in the middle of the experimental site with a fetch of more than $250 \mathrm{~m}$ in all directions. The meteorological parameters measured included wind speed and wind direction at a height of $8.5 \mathrm{~m}$, solar radiation, air temperature, and relative humidity at a height of $1.5 \mathrm{~m}$, as well as precipitation, soil temperature and soil moisture (Cobbett and Van Heyst, 2007). 
Table 1. Published mercury species concentrations and GEM fluxes measured from terrestrial surfaces.

\begin{tabular}{|c|c|c|c|c|c|c|c|}
\hline Location & Time of Year & Surface & $\begin{array}{l}\text { RGM } \\
\left(\mathrm{pg} \mathrm{m}^{-3}\right)\end{array}$ & $\begin{array}{l}\mathrm{HgP} \\
\left(\mathrm{pg} \mathrm{m}^{-3}\right)\end{array}$ & $\begin{array}{l}\text { GEM } \\
\left(\mathrm{ng} \mathrm{m}^{-3}\right)\end{array}$ & $\begin{array}{l}\text { GEM Flux } \\
\left(\mathrm{ng} \mathrm{m}^{-2} \mathrm{hr}^{-1}\right)\end{array}$ & Reference \\
\hline Ontario & Oct-Nov 2004 & Rural & $(0-21.7) 2.3$ & $(0-35.2) 3.0$ & $(0.2-42.1) 1.8$ & $(-2.9-3.6) 0.1$ & Cobbett and Van Heyst (2007) \\
\hline Tennessee & Spring and Summer 2004 & Rural & & & 1.79 & & Valente et al. (2007) \\
\hline Ohio & Jul 2004-Jul 2005 & Rural & 12.45 & (0-76.82) 5.29 & (0.78-4.38) 1.62 & & Yatavelli et al. (2006) \\
\hline Quebec & Jan-Dec 2003 & Rural & 3 & 26 & 1.65 & & Poissant et al. (2005) \\
\hline Michigan & Nov 2000-May 2001 & Rural & $(0.19-38.7)$ & & $(1.1-4.4)$ & & Lynman and Keeler (2005) \\
\hline Michigan & Jul 2000-Jul 2002 & Urban & $(0.6-270)$ & $(5.7-60.1)$ & (2.00-11.8) 4.1 & & Lynman and Keeler (2005) \\
\hline Minessota & May-Jun 2001 & Rural & & & & $(-91.7-190.5) 9.67$ & Cobos et al.(2002) \\
\hline Ireland & 1995-2001 & Rural & 18 & 8 & 1.77 & & Ebinghaus et al. (2001) \\
\hline Tennessee & 1992-1993 & Rural & $30-163$ & 100 & $1.93-2.35$ & & Lindberg and Stratton (1998) \\
\hline Zurich, Switzerland & Sep 2005-Aug 2006 & Rural & & & $(0.69-2.42) 1.42$ & $(-42-29)-2.9$ & Fritsche et al. (2008) \\
\hline $\begin{array}{l}\text { Present Study } \\
\text { (Elora, Ontario) }\end{array}$ & Nov 2006-Aug 2007 & Rural & 15.1 & (0.4-150.9) 16.4 & (0.08-5.97) 1.17 & $(-342.13-517.19) 6.31$ & \\
\hline
\end{tabular}

\subsection{Instrumentation and experimental set up}

During the experiment, ambient concentrations of the GEM, $\mathrm{RGM}$ and $\mathrm{Hg}^{\mathrm{P}}$ were continuously measured. GEM concentrations and GEM fluxes were measured using a Tekran 2537A mercury vapor analyzer while the concentrations of RGM and $\mathrm{Hg}^{\mathrm{P}}$ were measured using the Tekran 1130 and 1135 speciation units coupled to a second Tekran 2537A mercury vapor analyzer. $0.45 \mu$ Teflon $®$ filters were used at the sampling inlets of sample lines and the sampling inlet of the 2537A mercury vapor analyzer to remove any RGM in the flow and thus the mercury concentrations measured will be referred as GEM.

The Tekran 2537A analyzer was calibrated automatically every $25 \mathrm{~h}$ using its internal $\mathrm{Hg}$ permeation source. External calibrations using the Tekran 2505 with manual injections of known concentrations of $\mathrm{Hg}$ were performed every 4 months. Based on the calibration procedures, a detection limit of $0.1 \mathrm{ng} \mathrm{m}^{-3}$ was expected for the Tekran 2537A.

The Tekran 1130 and 1135 units sampled at a flow rate of $101 \mathrm{~min}^{-1}$ for a period of $2 \mathrm{~h}$. The RGM measurements used $\mathrm{KCl}$ coated denuders and were made according to Landis et al. (2002). After sampling, the Tekran 1130 denuder was desorbed $\left(500^{\circ} \mathrm{C}\right)$ and flushed. Once completed, the $\mathrm{Hg}^{\mathrm{P}}$ collected by the Tekran 1135 on a quartz filter was then thermally released by a pyrolysis heater $\left(800^{\circ} \mathrm{C}\right)$. During the desorption phases, the RGM and $\mathrm{Hg}^{\mathrm{P}}$ are converted to GEM which is then sent to the 2537A for analysis. The method detection limit is expected to be of $3.1 \mathrm{pg} \mathrm{m}^{-3}$ (Landis et al., 2002).

The sampling inlets were placed at a height of $1.5 \mathrm{~m}$ for the system used to measure the $\mathrm{Hg}$ species concentrations while for the system used to measure the GEM flux, the upper and lower intakes were positioned at $1.20 \mathrm{~m}$ and $0.35 \mathrm{~m}$, respectively during most of the study period (November 2006 to June 2007) and adjusted during the cropping season so that the lower intake was always $0.35 \mathrm{~m}$ above the ground cover with the height difference maintained between the upper and lower intakes.
During GEM flux measurements, ambient air was sampled alternately at the upper and lower intake with a sampling time of $10 \mathrm{~min}$, corresponding to 2 sampling phases of the Tekran 2537A mercury vapor analyzer. This removed any variability or line bias due to the individual cartridges. The air sample was drawn at a rate of $101 \mathrm{~min}^{-1}$ by a Teflon ${ }^{\circledR}$ lined vacuum pump (Model N035, KNF Neuberger) to ensure constant flow through the inlets, even when not being sampled by the Tekran 2537A, thus eliminating accumulation of air which might lead to the GEM being adsorbed on the inside wall of the Teflon ${ }^{\circledR}$ tubing. The vacuum pump was situated at the end of the sampling line after the Tekran 2537A inlet so as to avoid any risk of contamination from the pump. Each intake consisted of 4 inlets to avoid artificial flux due to flow distortion and to increase the spatial extent of the sampling (Edwards et al., 2005). The upper and lower intakes were connected to the Tekran Model 1110 Synchronized Two Port Sampling System to ensure the sampling switching between the 2 intake heights.

\section{Results and discussions}

The meteorological parameters measured for each season during the study period are summarized in Table 2 and were within the mean values recorded for the region over the past decades. Over the study period, the average air temperature, relative humidity $(\% \mathrm{RH})$, net radiation, and wind speed were $9.5 \pm 10.96^{\circ} \mathrm{C}($ mean $\pm \mathrm{SD}), 74.6 \pm 8.06 \%, 69 \mathrm{~W} \mathrm{~m}^{-2}$ and $9.9 \pm 5.90 \mathrm{~m} \mathrm{~s}^{-1}$, respectively. Summer 2007 was, however, a very dry summer. The annual precipitation for 2007 was $527 \mathrm{~mm}$ while the 1971-2000 normal annual rainfall is $770 \mathrm{~mm}$ (Environment Canada, 2007).

The mercury species were measured from day 305 in 2006 to day 225 in 2007 ( 1 November 2006 to 13 August 2007) while the GEM flux was measured up to day 180 (29 June 2007) with partly missing data in December, January and April due to an instrument failure. The average GEM, RGM and $\mathrm{Hg}^{\mathrm{P}}$ concentrations were $1.2 \pm 0.51 \mathrm{ng} \mathrm{m}^{-3}$, 
Table 2. Statistical summary of the environmental parameters measured during the study at Elora Research Station, ON from November 2006 to June 2007.

\begin{tabular}{|c|c|c|c|c|c|c|c|}
\hline Meteorological Parameter & Units & $n$ & Median & $\begin{array}{l}\text { Fall } 20 \\
\text { Mean }\end{array}$ & SD & Min & $\operatorname{Max}$ \\
\hline Air Temperature & $\left({ }^{\circ} \mathrm{C}\right)$ & 12577 & 4.2 & 5.0 & 6.56 & -21.1 & 25.4 \\
\hline Relative Humidity & $(\%)$ & 12577 & 84 & 81 & 12.65 & 29 & 98 \\
\hline Soil Moisture (1 cm depth) & $(\%)$ & 13110 & 41.4 & 40.4 & 4.92 & 3.7 & 47.3 \\
\hline Soil Moisture (30 cm depth) & $(\%)$ & 13110 & 43.7 & 43.7 & 4.21 & 13.9 & 54.6 \\
\hline Soil Temperature (1 cm depth) & $(\%)$ & 13110 & 5.1 & 5.8 & 4.69 & -6.1 & 20.1 \\
\hline Soil Temperature ( $30 \mathrm{~cm}$ depth) & $(\%)$ & 13110 & 6.1 & 6.8 & 3.92 & -4.5 & 16.9 \\
\hline Net Radiation & $\left(\mathrm{Wm}^{-2}\right)$ & 13110 & -4 & 26 & 106.6 & -107 & 629 \\
\hline Wind Speed & $\left(\mathrm{ms}^{-1}\right)$ & 13110 & 14 & 15 & 8.2 & 2 & 50 \\
\hline \multirow[t]{2}{*}{ Inverse Monin Obukhov Length } & $\left(\mathrm{m}^{-1}\right)$ & 13110 & 0.001 & -0.005 & 0.132 & -3.0 & 0.6 \\
\hline & & \multicolumn{6}{|c|}{ Winter 2007} \\
\hline Meteorological Parameter & Units & $n$ & Median & Mean & SD & Min & Max \\
\hline Air Temperature & $\left({ }^{\circ} \mathrm{C}\right)$ & 12511 & -5.8 & -6.0 & 7.10 & -25.6 & 17.5 \\
\hline Relative Humidity & $(\%)$ & 12511 & 83 & 80 & 11.38 & 34 & 98 \\
\hline Soil Moisture (1 cm depth) & $(\%)$ & 12672 & 19.2 & 24.7 & 11.81 & 13.3 & 46.4 \\
\hline Soil Moisture (30 cm depth) & $(\%)$ & 12672 & 42.4 & 42.9 & 2.47 & 33.3 & 49.9 \\
\hline Soil Temperature (1 cm depth) & $(\%)$ & 12672 & -1.3 & -1.3 & 2.82 & -9.0 & 7.8 \\
\hline Soil Temperature ( $30 \mathrm{~cm}$ depth) & $(\%)$ & 12672 & -0.5 & -0.5 & 2.65 & -8.0 & 7.8 \\
\hline Net Radiation & $\left(\mathrm{Wm}^{-2}\right)$ & 12672 & -7 & -8 & 51.9 & -115 & 347 \\
\hline Wind Speed & $\left(\mathrm{ms}^{-1}\right)$ & 12672 & 17 & 17 & 9.3 & 2 & 52 \\
\hline \multirow[t]{2}{*}{ Inverse Monin Obukhov Length } & $\left(\mathrm{m}^{-1}\right)$ & 12672 & 0.001 & -0.005 & 0.169 & -3.0 & 1.2 \\
\hline & & \multicolumn{6}{|c|}{ Spring 2007} \\
\hline Meteorological Parameter & Units & $n$ & Median & Mean & SD & Min & Max \\
\hline Air Temperature & $\left({ }^{\circ} \mathrm{C}\right)$ & 13170 & 10.8 & 11.4 & 9.22 & -11.0 & 32.3 \\
\hline Relative Humidity & $(\%)$ & 13170 & 68 & 65 & 20.69 & 15 & 97 \\
\hline Soil Moisture (1 cm depth) & $(\%)$ & 4267 & 39.1 & 37.2 & 7.51 & 14.3 & 48.9 \\
\hline Soil Moisture (30 cm depth) & $(\%)$ & 4267 & 45.3 & 46.3 & 2.62 & 21.2 & 51.3 \\
\hline Soil Temperature (1 cm depth) & $(\%)$ & 13242 & 11.8 & 11.6 & 7.72 & -3.5 & 27.4 \\
\hline Soil Temperature ( $30 \mathrm{~cm}$ depth) & $(\%)$ & 13242 & 10.5 & 10.2 & 6.28 & -3.0 & 27.4 \\
\hline Net Radiation & $\left(\mathrm{Wm}^{-2}\right)$ & 13242 & 10 & 111 & 209.3 & -116 & 808 \\
\hline Wind Speed & $\left(\mathrm{ms}^{-1}\right)$ & 13242 & 13 & 14 & 8.0 & 2 & 47 \\
\hline \multirow[t]{2}{*}{ Inverse Monin Obukhov Length } & $\left(\mathrm{m}^{-1}\right)$ & 13242 & -0.001 & -0.007 & 0.125 & -3.0 & 0.9 \\
\hline & & \multicolumn{6}{|c|}{ Summer 2007} \\
\hline Meteorological Parameter & Units & $n$ & Median & Mean & SD & Min & $\operatorname{Max}$ \\
\hline Air Temperature & $\left({ }^{\circ} \mathrm{C}\right)$ & 9743 & 20.1 & 19.9 & 5.69 & 4.4 & 33.3 \\
\hline Relative Humidity & $(\%)$ & 9743 & 75 & 71 & 19.35 & 26 & 97 \\
\hline Soil Moisture (1 cm depth) & $(\%)$ & 5904 & 20.7 & 22.1 & 3.25 & 13.3 & 36.7 \\
\hline Soil Moisture (30 cm depth) & $(\%)$ & 5904 & 30.4 & 30.8 & 0.94 & 27.1 & 33.1 \\
\hline Soil Temperature (1 cm depth) & $(\%)$ & 9742 & 18.9 & 18.7 & 3.31 & 7.9 & 30.7 \\
\hline Soil Temperature ( $30 \mathrm{~cm}$ depth) & $(\%)$ & 9742 & 17.9 & 17.7 & 2.28 & 12.0 & 26.7 \\
\hline Net Radiation & $\left(\mathrm{Wm}^{-2}\right)$ & 9311 & 33 & 147 & 225.8 & -104 & 912 \\
\hline Wind Speed & $\left(\mathrm{ms}^{-1}\right)$ & 9742 & 9 & 10 & 5.9 & 2 & 34 \\
\hline Inverse Monin Obukhov Length & $\left(\mathrm{m}^{-1}\right)$ & 9742 & 0.000 & 0.002 & 0.049 & -0.1 & 0.8 \\
\hline
\end{tabular}

$15.1 \pm 10.02 \mathrm{pg} \mathrm{m}^{-3}$ and $16.3 \pm 9.54 \mathrm{pg} \mathrm{m}^{-3}$ respectively. A detailed breakdown of the mean and standard deviation by month, season and overall study period for the current study is given in Table 3 .

\subsection{GEM concentrations}

Monthly means of GEM ranged from 0.8 up to $1.4 \mathrm{ng} \mathrm{m}^{-3}$ with the lowest value recorded in July and the highest value recorded in both November and December. The mean 
Table 3. Average monthly and seasonal $\mathrm{Hg}$ species concentrations and GEM flux measured at Elora, ON (November 2006-August 2007) over different ground covers.

\begin{tabular}{|c|c|c|c|c|c|c|c|c|c|}
\hline & $\begin{array}{l}\text { Average GEM Conc } \\
\left(\mathrm{ng} \mathrm{m}^{-3}\right)\end{array}$ & SD & $\begin{array}{l}\text { Average RGM Conc } \\
\left(\mathrm{pg} \mathrm{m}^{-3}\right)\end{array}$ & SD & $\begin{array}{l}\text { Average } \mathrm{Hg}^{P} \text { Conc } \\
\quad\left(\mathrm{pg} \mathrm{m}^{-3}\right)\end{array}$ & SD & $\begin{array}{l}\text { Average GEM Flux } \\
\quad\left(\mathrm{ng} \mathrm{m}^{-2} \mathrm{hr}^{-1}\right)\end{array}$ & SD & $\begin{array}{l}\text { Ground } \\
\text { Cover }\end{array}$ \\
\hline \multicolumn{10}{|l|}{ Month } \\
\hline Nov & 1.4 & 0.25 & 17.2 & 8.30 & 22.0 & 10.59 & 0.0 & 9.50 & Bare \\
\hline Dec & 1.4 & 0.86 & 10.8 & 7.24 & 12.6 & 7.36 & -0.4 & 9.63 & Snow \\
\hline Jan & 0.9 & 0.14 & 17.6 & 12.37 & 13.4 & 8.76 & 0.5 & 12.38 & Snow \\
\hline Feb & 0.9 & 0.14 & 9.2 & 5.57 & 13.8 & 10.42 & 1.2 & 18.12 & Snow \\
\hline Mar & 1.1 & 0.27 & & & & & 9.2 & 28.10 & Bare \\
\hline Apr & 1.0 & 0.34 & 34.9 & 24.81 & 24.5 & 6.63 & 18.1 & 42.87 & Bare \\
\hline May & 1.3 & 0.38 & 17.4 & 10.03 & 19.5 & 10.29 & & & Corn \\
\hline Jun & 1.2 & 0.46 & 17.9 & 9.26 & 17.4 & 5.20 & 15.2 & 59.49 & Corn \\
\hline Jul & 0.8 & 0.64 & 13.3 & 13.58 & 7.9 & 7.42 & & & Corn \\
\hline Aug & 1.1 & 0.70 & 10.2 & 5.28 & 11.8 & 5.42 & & & Corn \\
\hline \multicolumn{10}{|l|}{ Seasons } \\
\hline Fall & 1.3 & 0.53 & 14.0 & 8.50 & 17.3 & 10.23 & -0.1 & 9.54 & Bare/Snow \\
\hline Winter & 0.9 & 0.61 & 12.5 & 9.51 & 13.5 & 9.67 & 2.5 & 21.18 & Snow/Bare \\
\hline Spring & 1.3 & 0.63 & 17.9 & 4.82 & 19.5 & 9.22 & 19.5 & 9.22 & Bare/Corn \\
\hline Summer & 1.1 & 0.44 & 13.9 & 10.88 & 12.2 & 2.94 & 17.0 & 79.43 & Corn \\
\hline Overall & 1.2 & 0.51 & 15.1 & 10.02 & 16.4 & 9.54 & 6.3 & 33.98 & \\
\hline
\end{tabular}

monthly GEM concentrations, however, do not display a very consistent behaviour from one month to the next. However, the standard deviation for the data tends to be smaller during the fall and winter months with higher variation in the spring and summer months. The exception to this trend is December, which had the highest standard deviation of $\pm 0.86 \mathrm{ng} \mathrm{m}^{-3}$. On a seasonal basis, the GEM concentrations showed some variability with the winter and summer values lower than that for the spring and the fall but the magnitudes of the standard deviations make the differences statistically insignificant and thus the GEM mean concentration for the study period of $1.2 \pm 0.51 \mathrm{ng} \mathrm{m}^{-3}$ best describes the GEM behaviour. This annual average GEM concentration is lower than that reported by other studies for rural areas (see Table 1).

The behaviour of the GEM concentration on a seasonal average day is given in Fig. 2. In fall and spring, the diurnal pattern had the highest concentrations recorded at midday and early afternoon when the net radiation and air temperature were typically highest. A similar but weaker diurnal trend was observed in winter and is explained by the weaker variations observed in January and February (Fig. 3) when the ground was covered with snow. The magnitudes of GEM concentrations were highest in the fall followed closely by the spring values and with the winter values typically being less than $1 \mathrm{ng} \mathrm{m}^{-3}$ throughout the average day. For the summer, an opposite trend to the other seasons with lowest concentrations recorded during the afternoon was observed.

Results of the generalized linear model (GLM) analysis indicate that, over the whole study period, net radiation ( $p=0.032)$ was the main environmental factor influencing the concentrations of GEM. The average monthly behaviour of the GEM concentration versus the monthly average net

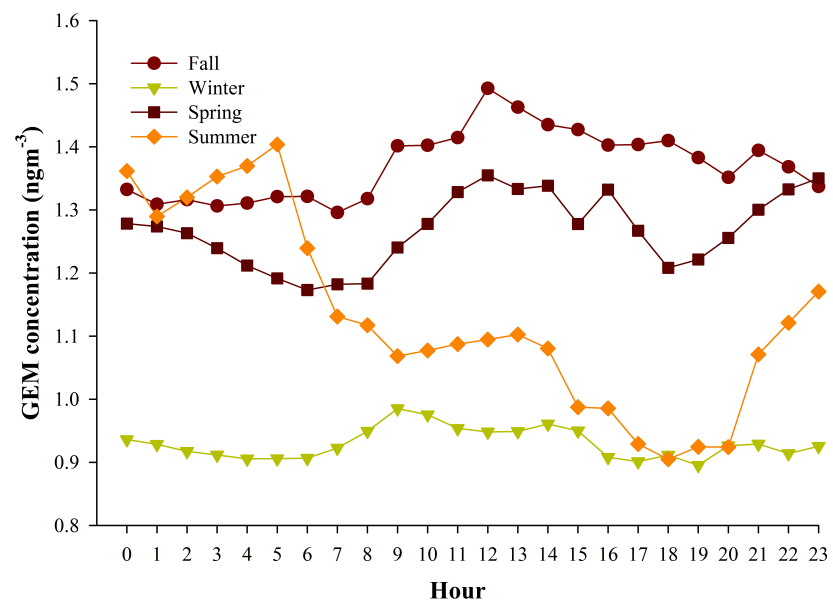

Fig. 2. Seasonal average day behaviour of GEM concentrations $\left(\mathrm{ng} \mathrm{m}^{-3}\right)$ measured during the study at Elora Research Station, ON (1 November 2006 to 29 June 2007).

radiation is depicted in Fig. 3 and illustrates that for the first half of the year, the GEM concentration and net radiation increased in a similar manner. After June, the behaviour of the GEM concentrations deviate from that of the net radiation which is consistent with the trends observed in the average day concentrations. In late fall and early winter, the GEM concentrations were elevated in comparison to the net radiation levels presumably due to an increased influence of anthropogenic activities brought about by a shift in the dominant wind direction (see Fig. 5).

The different behaviour of the GEM concentrations in the summer period is attributed mainly to the different meteorological conditions, namely the atmospheric stability, 


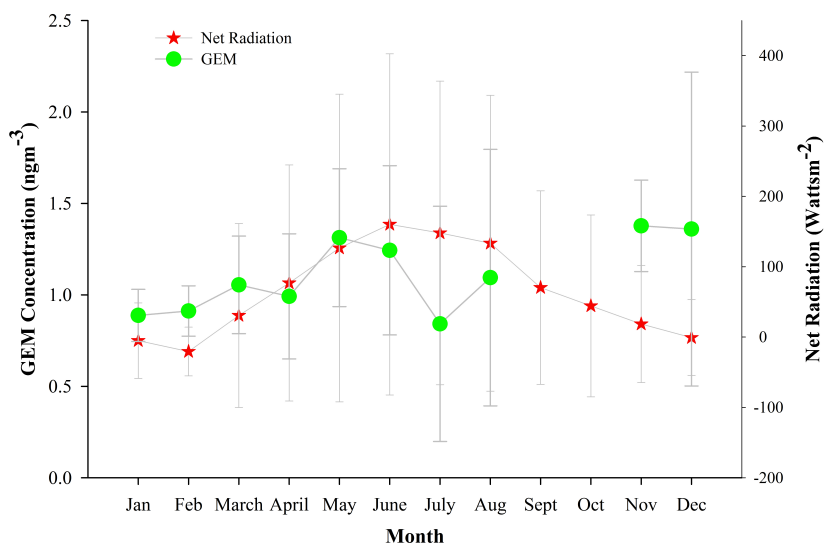

Fig. 3. Average monthly GEM concentrations $\left(\mathrm{ng} \mathrm{m}^{-3}\right)$ and net radiation (wattsm ${ }^{-2}$ ) measured during the study at Elora Research Station, ON (1 November 2006 to 29 June 2007).

observed in the summer. Figure 4 depicts the seasonal average hourly inverse Monin Obukhov length scale $\left(\mathrm{m}^{-1}\right)$ which is an indication of the atmospheric stability. For the winter period, the atmosphere was relatively stable resulting in a reduced mixing height while during the warmer periods of the year, especially in the summer, the boundary layer height was higher and more unstable during the daylight hours resulting in more turbulent mixing and dilution of the pollutants. Thus any increases in GEM concentrations due to the increase in the net radiation in the summer would be difficult to observe as the increased turbulent mixing would quickly transport the GEM away from the surface and thus lower the concentrations near the soil surface during the daytime. At night, when the atmosphere is more stable, a concentration of GEM would build up near the surface as is indicated in Fig. 2.

Other environmental parameters that influenced the concentration of GEM on a seasonal basis included: soil temperature, soil moisture and wind speed and direction. Unfortunately, these parameters did not have a consistent effect across all seasons thus illustrating that the influence of environmental parameters on GEM concentrations can be seasonally dependent and confounded and should not be assumed constant throughout the year.

As an example, Fig. 5 illustrates the role of wind direction as an important factor influencing GEM concentrations in the atmosphere. High GEM concentrations $\left(>2.0 \mathrm{ng} \mathrm{m}^{-3}\right.$ ) were recorded mainly when the wind was from the westsouthwest (WSW) sector, especially for the fall, where there are suspected industrial sources. These frequent high concentrations from the WSW sector in the fall also explain why the fall season had elevated GEM concentrations above the net radiation as the generation of GEM may not have been from the soil alone.

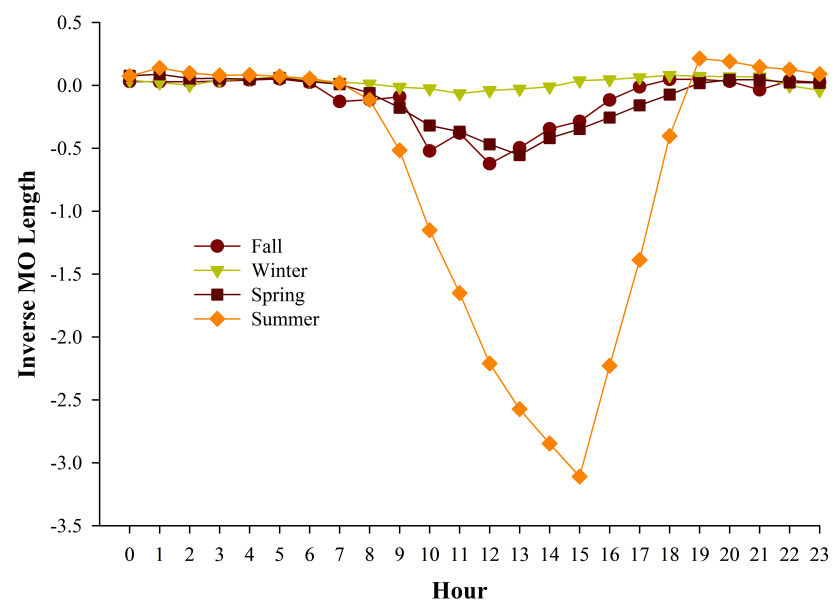

Fig. 4. Seasonal hourly average values for the inverse Monin Obukhov (MO) length $(1 / L)\left(\mathrm{m}^{-1}\right)$ measured from 1 November 2006 to 29 June 2007 measured at Elora Research Station, ON. $1 / L>0$ indicates stable atmospheric conditions, $1 / L=0$ indicates neutral atmospheric conditions and $1 / L<0$, indicates unstable atmospheric conditions.
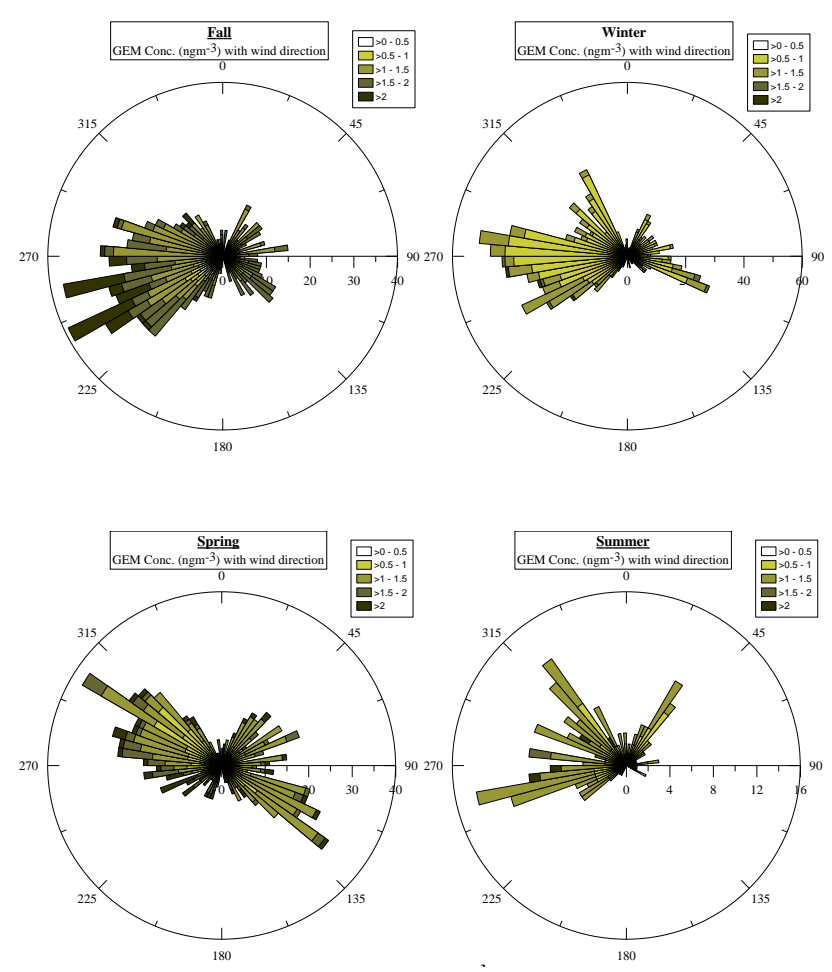

Fig. 5. Pollution roses of GEM concentrations $\left(\mathrm{ng} \mathrm{m}^{-3}\right)$ for each season measured at Elora, ON during the study period (1 November 2006 to 29 July 2007). The concentrations (hourly average) intervals are plotted against the frequency of occurrence on the radius axis. 


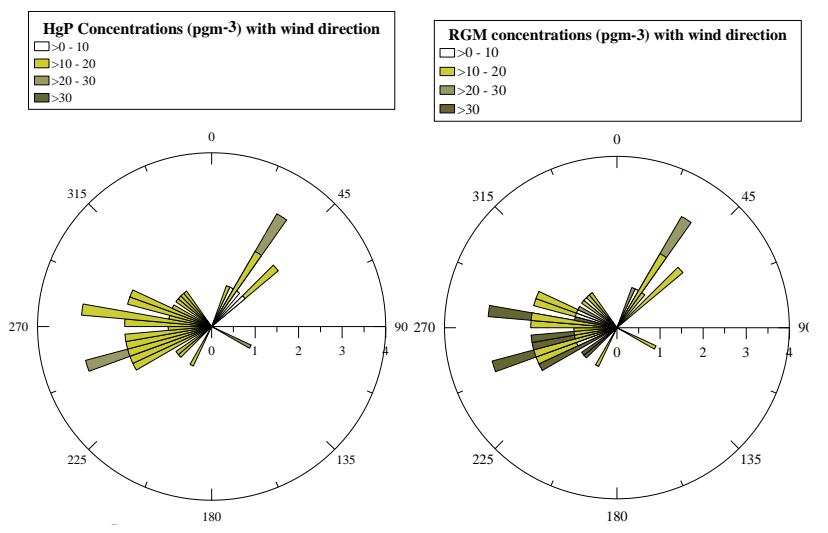

Fig. 6. $\mathrm{Hg}^{\mathrm{P}}$ and $\mathrm{RGM}$ concentrations range with wind direction from 24 to 28 June 2007 during the study at Elora Research Station, ON showing the influence of wind direction on the $\mathrm{Hg}$ species concentration.

\subsection{RGM and $\mathrm{Hg}^{\mathrm{P}}$ concentrations}

Monthly values for RGM and $\mathrm{Hg}^{\mathrm{P}}$, given in Table 3, display no clear monthly trend although April had the highest concentrations for both RGM and $\mathrm{Hg}^{\mathrm{P}}$. When aggregated on a seasonal basis, the spring season had the highest concentrations for both RGM and $\mathrm{Hg}^{\mathrm{P}}$ due to the elevated levels reported for April. In addition, the average seasonal concentration was higher for $\mathrm{Hg}^{\mathrm{P}}$ than for RGM for the fall, winter, and spring whereas the summer experienced higher concentrations of RGM over $\mathrm{Hg}^{\mathrm{P}}$. The observed concentrations of $\mathrm{RGM}$ and $\mathrm{Hg}^{\mathrm{P}}$ in the current study are consistent with those reported in the literature (see Table 1) albeit the range of the current $\mathrm{Hg}^{\mathrm{P}}$ concentrations is larger than that previously observed.

For the current study, RGM and $\mathrm{Hg}^{\mathrm{P}}$ concentrations did not exhibit any predictable statistically significant diurnal, monthly or seasonal patterns during the study period nor statistically significant relationships with environmental parameters. The elevated RGM and $\mathrm{Hg}^{\mathrm{P}}$ concentrations are believed to be mainly due to agricultural activities occurring in the area and/or the result of polluted air being transported to the site. Higher RGM and $\mathrm{Hg}^{\mathrm{P}}$ concentrations were recorded in the spring, typically when the soil was tilled, nutrient amendments added and crops planted and cultivated, as well as in the fall when the crops were harvested and land was ploughed.

The significance of potential polluted air masses being transported to site is illustrated in Fig. 6 which gives pollution roses for $\mathrm{RGM}$ and $\mathrm{Hg}^{\mathrm{P}}$ during a significant four day event. The pollution roses indicate that higher RGM and $\mathrm{Hg}^{\mathrm{P}}$ concentrations were recorded when the wind was blowing from the western direction which is in the direction of some industrial sources.

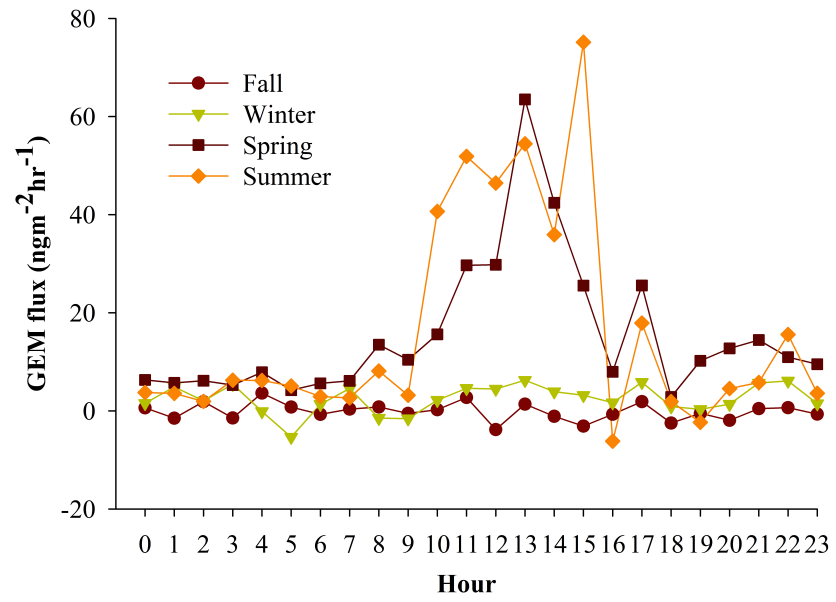

Fig. 7. Seasonal average day behaviour of GEM fluxes (ng m ${ }^{-2} \mathrm{hr}^{-1}$ ) measured at Elora Research Station, ON study site (1 November 2006 to 29 June 2007).

\subsection{GEM flux}

Monthly and seasonal GEM flux data are given in Table 3 although, due to technical difficulties with the Tekran 2537A, data for May, July and August were not obtained. Of the months with data, only December showed an average deposition of GEM to the soil surface although November indicated a zero flux. During these two months, winds from the WSW sector with large GEM concentrations were a frequent occurrence and thus the imported atmospheric GEM burden above the soil may have equaled or been greater to that emitted from the surface and hence the resulting zero or net deposition.

Figure 7 gives the seasonal average day behaviour of the GEM flux above the substrate (i.e. bare soil, snow, or crop canopy) and illustrates the large fluxes that occurred in the spring and summer during daytime hours. The GEM flux in the fall and winter behaved differently and displayed very little variation throughout the average day.

The average annual GEM flux was $6.3 \pm 3.98 \mathrm{ng} \mathrm{m}^{-2}$ $\mathrm{hr}^{-1}$, which is a net volatilization to the atmosphere. The average GEM flux obtained is higher than that reported by Cobbett and Van Heyst (2007) and Fritsche et al. (2008) but lower than that given by Cobos et al. (2002).

The generalized linear model (GLM) analysis indicated that solar radiation, soil and air temperature and soil moisture content were all significant factors on the GEM flux. Furthermore, precipitation events and ground cover also had strong influences on the GEM flux to the atmosphere. The effects of these parameters will be discussed in greater detail in the following subsections.

\subsubsection{Solar radiation and temperature}

Net solar radiation was the main factor influencing GEM fluxes above the various surfaces $(p>0.0001)$. Increased 


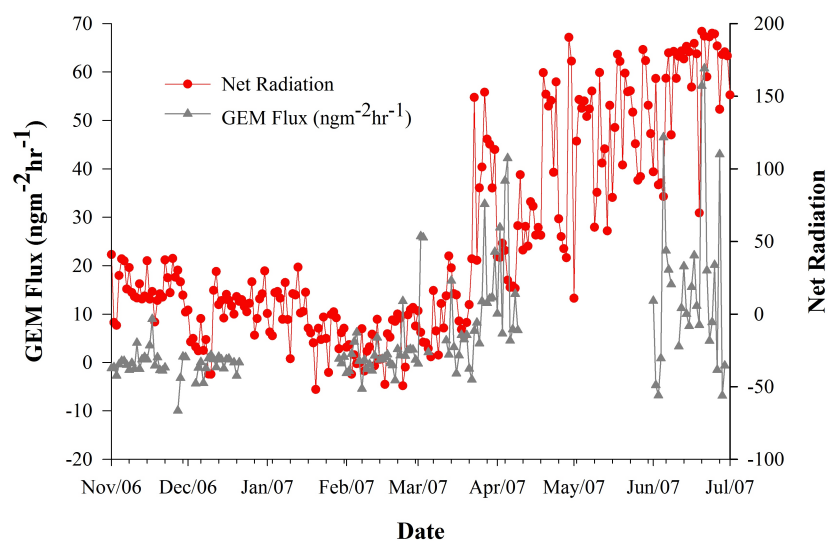

Fig. 8. Daily averages of GEM flux $\left(\mathrm{ng} \mathrm{m}^{-2} \mathrm{hr}^{-1}\right)$, net radiation $\left(\right.$ Wattsm $^{-2}$ ) and relative humidity (\% RH) with time (1 November 2006 to 29 June 2007) measured at Elora Research Station, ON.

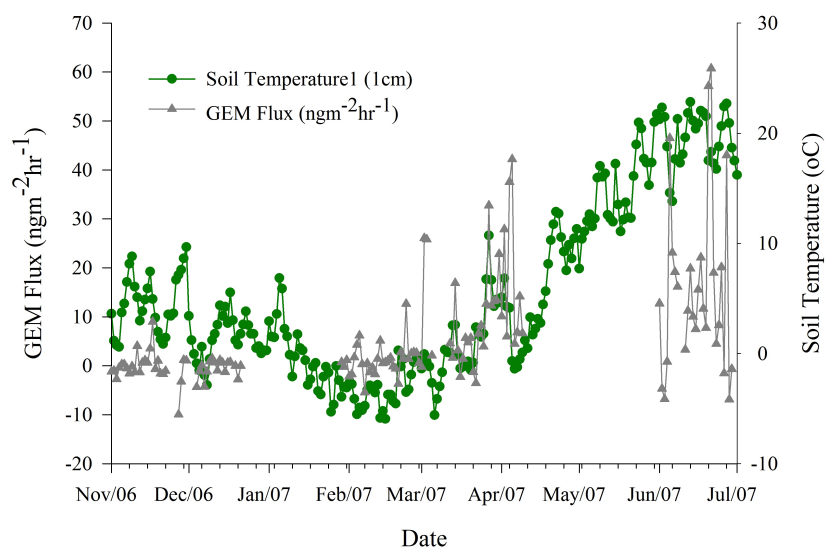

Fig. 9. Daily averages of GEM flux $\left(\mathrm{ng} \mathrm{m}^{-2} \mathrm{hr}^{-1}\right)$ and soil temperature $\left({ }^{\circ} \mathrm{C}\right)$ with time (1 November 2006 to 29 June 2007) measured at Elora Research Station, ON.

GEM volatilization (up to $517 \mathrm{ng} \mathrm{m}^{-2} \mathrm{hr}^{-1}$ ) was recorded at moderate soil and air temperatures $\left(>5^{\circ} \mathrm{C}\right)$ as a result of high net radiation (up to $300 \mathrm{~W} \mathrm{~m}^{-2}$ ). The effect of radiation on GEM fluxes is demonstrated in Fig. 8 where the daily averaged GEM flux is plotted against the daily average net radiation from fall to summer. The increase in volatilization and the more pronounced diurnal pattern (Fig. 7) is evident starting in spring months (mid March to April - days 75 to 100 as well as in June - days 152 to 181). In winter there is reduced volatilization and relatively less variation in the volatilization rate due to reduced net radiation intensity and amplitude suggesting that, during winter, net radiation might not be the most dominant environmental factor influencing the magnitude of the GEM flux.

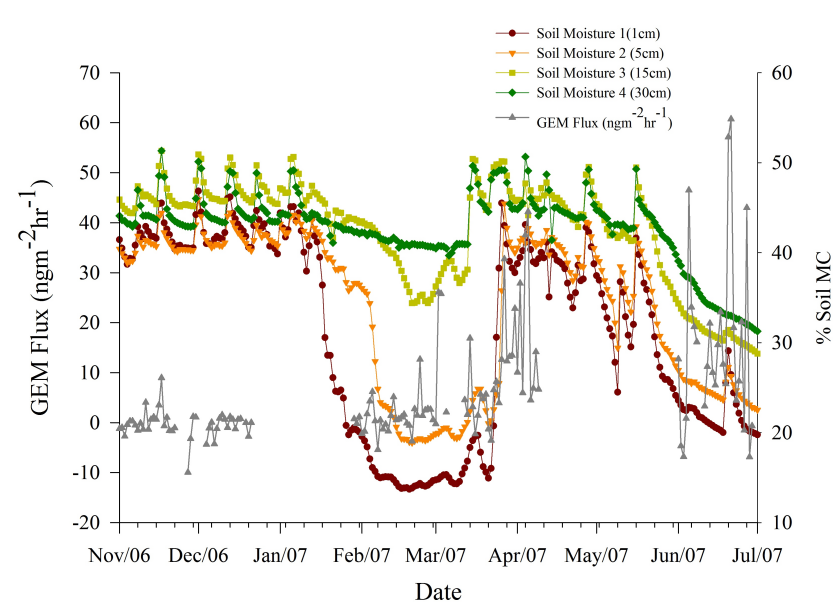

Fig. 10. Daily averages of GEM flux $\left(\mathrm{ng} \mathrm{m}^{-2} \mathrm{hr}^{-1}\right)$ and soil moisture content $(\%)$ with time (1 November 2006 to 29 June 2007) measured at Elora Research Station, ON.

\subsubsection{Soil temperature and moisture content}

Figures 9 and 10 display the behaviour of the GEM flux against the soil temperature and soil moisture respectively. From Fig. 9, the GEM flux during the fall of 2006 and winter of 2007, was relatively constant although a few episodes occurred with high GEM fluxes despite the reduced net radiation. These events, which typically occurred when the soil temperature was below freezing $\left(\leq-5^{\circ} \mathrm{C}\right)$, had observed hourly GEM fluxes as high as $130 \mathrm{ng} \mathrm{m}^{-2} \mathrm{hr}^{-1}$ suggesting, that under certain conditions (low net radiation in winter), the soil conditions may be more important in controlling the GEM flux. As with the net radiation, from mid March and into April, high daily GEM fluxes corresponded to increasing soil temperatures as the spring thaw was underway. For June, the high GEM fluxes occurred with the warm soil temperatures.

During the winter, the surface soil moisture content was relatively low $(<20 \%)$ although the deeper soils $(>15 \mathrm{~cm}$ depth) were relatively moist and unaffected by the drying of the surface (see Fig. 10). The high GEM fluxes observed under the winter time (up to $26 \mathrm{ng} \mathrm{m}^{-2} \mathrm{hr}^{-1}$ ) with low soil temperatures may be the result of the deeper soil water freezing and causing a reduction in the pore space due to the greater volume of ice and thus forcing soil interstitial air from the soil matrix producing winter time spikes in GEM fluxes.

The behaviour of soil moisture (Fig. 10) also supports the idea of the spring thaw greatly affecting the magnitude of the GEM fluxes. One factor that may cause an increase in the GEM flux is, as the surface soil moisture is replenished from values less than $20 \%$ to approximately $40 \%$ during the spring thaw, air within the soil matrix must be vented to allow the increase in soil moisture to occur. This displaced soil air may directly contribute to the elevated GEM flux (Song and Van Heyst, 2005) and may also promote greater aqueous 


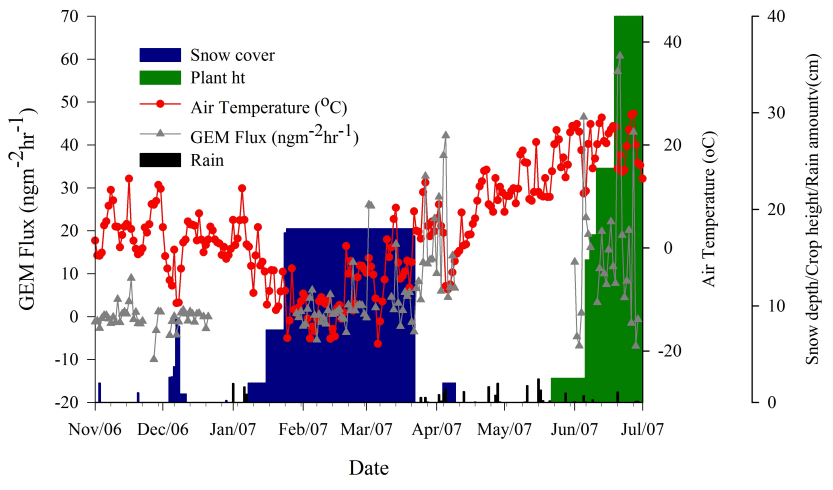

Fig. 11. GEM flux $\left(\mathrm{ng} \mathrm{m}^{-2} \mathrm{hr}^{-1}\right)$, air temperature $\left({ }^{\circ} \mathrm{C}\right)$, precipitation $(\mathrm{mm})$ and crop cover $(\mathrm{cm})$ with time (1 November 2006 to 29 June 2007) measured at Elora Research Station, ON. The days with snow cover and crop cover are highlighted.

conversion of bound mercury to elemental mercury within the soil matrix where it can be transported to the soil surface and released into the atmosphere.

The high GEM fluxes recorded in June occurred during periods when the soil matrix was drying, especially at the surface. As the soil dries, more room is made for interstitial soil air and less aqueous chemical conversion would occur thus suggesting that a decrease in GEM flux should have occurred if the soil moisture was the only controlling factor. As such, the data indicates that net radiation and soil temperature have more of a controlling influence on the GEM flux during this time period. A GEM flux spike did occur in June following a major precipitation event as evident by the increase in surface moisture content thus expelling air from the soil pore spaces.

\subsubsection{Ground cover}

Low GEM fluxes were observed in late winter (January and February - see Table 3) when the ground was covered with snow as illustrated in Fig. 11. The reduced GEM flux is due to the reduced air exchange between the soil surface and the atmosphere. Furthermore, the snow cover (up to $18 \mathrm{~cm}$ recorded) may have reduced GEM volatilization to the atmosphere by preventing light penetration (already of lower intensity in winter) thus tempering the effect on the $\mathrm{Hg}$ volatilization rate.

As discussed above with soil moisture, the disappearance of the snow cover during the spring thaw resulted in an increase in the GEM flux as seen in Fig. 11 which again supports the influence of soil moisture on the GEM flux. Crop covers (see results for June and July, 2007 in Fig. 11) also affected the soil moisture content by increasing evapotranspiration and modulating the surface soil temperature by canopy shading. Furthermore, crop covers could be expected to have a similar effect as snow cover in filtering the quantity and quality of the solar radiation reaching the soil surface.

\subsubsection{Precipitation events}

Figure 10 shows that the GEM flux peaks with each episode of increase in soil moisture as a result of rain (in summer mainly) or snow melting (late winter) while Fig. 11 shows the GEM flux with precipitation events and ground cover. In summer the soil moisture decreased to below $30 \%$ at $30 \mathrm{~cm}$ depth (18 June). The next precipitation event $(10 \mathrm{~mm})$ resulted in GEM flux up to $60 \mathrm{ng} \mathrm{m}^{-2} \mathrm{hr}^{-1}$ indicating that increase in GEM fluxes as a response to increasing soil moisture is greater when the soil moisture before the precipitation event is lower (19-21 June). This can be explained by an increasing volume of air in the soil pore spaces in as the soil moisture decreases thus resulting in a greater volume of air being expelled when water penetrates the soil and fills the pore spaces during a precipitation event. Similar observations were made by Song and Van Heyst (2005) in a study conducted in the lab where greatest volatilization was recorded after precipitation on dry soil.

\section{Conclusions}

The average GEM, RGM and $\mathrm{Hg}^{\mathrm{P}}$ concentrations measured during the study over agricultural land were $\quad 1.17 \pm 0.51 \mathrm{ng} \mathrm{m}^{-3}, \quad 15.10 \pm 10.02 \mathrm{pg} \mathrm{m}^{-3}$ and $16.35 \pm 9.54 \mathrm{pg} \mathrm{m}^{-3}$ while the average annual GEM flux was $6.31 \pm 33.98 \mathrm{ng} \mathrm{m}^{-2} \mathrm{hr}^{-1}$.

The measurement of $\mathrm{Hg}$ species and GEM flux over four consecutive seasons demonstrates that different behaviours occurred for GEM concentrations and GEM flux to the atmosphere while RGM and $\mathrm{Hg}^{\mathrm{P}}$ were not greatly affected by the changing seasons.

Net radiation and air temperature proved to be the main environmental factor influencing GEM concentrations and fluxes, which exhibited clear seasonal and diurnal trends. The influence of soil conditions namely soil temperature and soil moisture content was demonstrated during numerous episodes where positive fluxes were recorded as a result of increasing soil moisture after precipitation events or snow melting. The wind direction had a strong influence on all the $\mathrm{Hg}$ species concentrations by presumably bringing polluted air to the site.

It should be pointed out that even if the main factors controlling the $\mathrm{Hg}$ species and GEM flux to the atmosphere have been identified above, no strong direct correlation was observed when analyzing the response of the different mercury species to the controlling environmental parameters. This lack of correlation suggests that the environmental parameters have a more combined effect rather than separate independent effects on the $\mathrm{Hg}$ species and behaviour at the soil and air interface. This is well demonstrated in summer when lower GEM concentrations were recorded compared to fall and spring despite high radiation and air temperature due to an unstable atmosphere and more mixing. 
Similarly, a net deposition for December was observed while there were episodes later in winter when high GEM fluxes were recorded due to the combined effect of decreasing soil temperature and soil water freezing.

Acknowledgements. The study was funded by the Natural Sciences and Engineering Research Council of Canada (NSERC), the Canadian Bureau for International Education (CBIE) and the School of Engineering, University of Guelph. The authors would like to express their gratitude to Frank Cobbett and Paul Caplat for their valuable scientific and technical contributions and the Land resource Science department, University of Guelph especially Dean Doulittle and Jon Warland for the use of their experimental area.

Edited by: R. Ebinghaus

\section{References}

Cobbett, F. D., Steffen, A., Lawson, G., and Van Heyst, B. J.: GEM fluxes and atmospheric mercury concentrations (GEM, RGM and Hgp) in the Canadian Arctic at Alert, Nunavut, Canada (February-June 2005), Atmos. Environ., in press, 2007.

Cobbett, F. D. and Van Heyst, B. J.: Measurements of GEM fluxes and atmospheric mercury concentrations (GEM, RGM and Hgp) from an agricultural field amended with biosolids in Southern Ont., Canada (October 2004-November 2004), Atmos. Environ., 41(31), 6527-6543, 2007.

Cobos, D. R., Baker, J. M., and Nater, E. A.: Conditional sampling for measuring mercury vapor fluxes, Atmos. Environ., 36(27), 4309-4321, 2002.

Ebinghaus, R., Kock, H., and Schmolke, S.: Measurements of atmospheric mercury with high time resolution: Recent applications in environmental research and monitoring, Fresenius' J. Anal. Chem., 371(6), 806-815, 2001.

Edwards, G. C., Rasmussen, P. E., Schroeder, W. H., Wallace, D. M., Halfpenny-Mitchell, L., Dias, G. M., Kemp, R. J., and Ausma, S.: Development and evaluation of a sampling system to determine gaseous Mercury fluxes using an aerodynamic micrometeorological gradient method, J. Geophys. Res., 110, D10306, doi:10.1029/2004JD005187, 2005.

Engle, M. A., Gustin, M. S., and Zhang, H.: Quantifying natural source mercury emissions from the Ivanhoe Mining District, north-central Nevada, USA, Atmos. Environ., 35(23), 39873997, 2001.

Environment Canada: National climate archives, available online at: http://www.climate.weatheroffice.ec.gc.ca, last access: October 2007.

Fitzgerald, W. F.: Is mercury increasing in the atmosphere? The need for an atmospheric mercury network (AMNET), Water Air Soil Pollut., 80(1), 245-254, 1995.

Fritsche, J., Obrist, D., Zeeman, M., Conen, F., Eugster, W., and Alewell, C.: Elemental mercury fluxes over a sub-alpine grassland determined with two micrometeorological methods, Atmos. Environ., 42(13), 2922-2933, 2008.

Gustin, M. S., Taylor, G. E., and Taylor, R.: Effect of temperature and air movement on the flux of elemental mercury from substrate to the atmosphere, J. Geophys. Res., 102(D3), 3891-3898, 1997.
Gustin, M. S.: Are mercury emissions from geologic sources significant? A status report, Sci. Total Environ., 304(1-3), 153-167, 2003.

Iverfeldt, A. and Lindqvist, O.: Atmospheric oxidation of elemental mercury by ozone in the aqueous phase, Atmos. Environ., 20(8), 1567-1573, 1986.

Landis, M. S., Stevens, R. K., Schaedlich, F., and Prestbo, E. M.: Development and Characterization of an Annular Denuder Methodology for the Measurement of Divalent Inorganic Reactive Gaseous Mercury in Ambient Air, American Chemical Society, Easton, $\mathrm{Pa}, 2002$.

Lin, C. and Pehkonen, S. O.: The chemistry of atmospheric mercury: a review, Atmos. Environ., 33(13), 2067-2079, 1999.

Lindberg, S., Bullock, R., Ebinghaus, R., Engstrom, D., Feng, X., Fitzgerald, W., Pirrone, N., Prestbo, E., and Seigneur, C.: A Synthesis of Progress and Uncertainties in Attributing the Sources of Mercury in Deposition, Ambio, 36(1), 19-32, 2007.

Lindberg, S. E., Kim, Ki-Hyun, Meyers, T. P., and Owens, J. G.: Micrometeorological Gradient Approach for Quantifying Air/Surface Exchange of Mercury Vapor: Tests Over Contaminated Soils, American Chemical Society, Easton, Pa, 1995.

Lynam, M. M. and Keeler, G. J.: Automated Speciated Mercury Measurements in Michigan, Environ. Sci. Technol., 39(23), 9253-9262, 2005.

Mason, R. P., Fitzgerald, W. F., and Morel, F. M. M.: The biogeochemical cycling of elemental mercury: anthropogenic influences, Pergamon Press., Oxford, 1994.

Mason, R. P. and Sheu, G.-R.: Role of the ocean in the global mercury cycle, Global Biogeochem. Cy., 16(4), 1093, doi:10.1029/2001GB001440, 2002.

Munthe, J.: Aqueous Oxidation of Elemental Mercury by Ozone. Atmospheric Enviro. A, 26, 1461-1468, doi:10.1016/09601686(92)90131-4, 1992.

Obrist, D., Gustin, M. S., Arnone III, J. A., Johnson, D. W., Schorran, D. E., and Verburg, P. S. J.: Measurements of gaseous elemental mercury fluxes over intact tallgrass prairie monoliths during one full year, Atmos. Environ., 39(5), 957-965, 2005.

Poissant, L., Pilote, M., and Casimir, A.: Mercury flux measurements in a naturally enriched area: Correlation with environmental conditions during the Nevada Study and Tests of the Release of Mercury From Soils (STORMS), J. Geophys. Res., 104(D17), 845-858, 1999.

Poissant, L., Pilote, M., Beauvais, C., Constant, P., and Zhang, H. 2005: A year of continuous measurements of three atmospheric mercury species (GEM, RGM and Hgp) in southern Québec, Canada, Atmos. Environ., 39(7), 1275-1287, 2005.

Satoh, H.: Occupational and Environmental Toxicology of Mercury and Its Compounds, Industrial Health-Kawasaki, 38(2), 153$164,2000$.

Schroeder, W. H. and Munthe, J.: Atmospheric mercury-An overview, Atmos. Environ., 32(5), 809-822, 1998.

Seigneur, C., Vijayaraghavan, K., Lohman, K., Karamchandani, P., and Scott, C.: Global Source Attribution for Mercury Deposition in the United States, Environ. Sci. Technol., 38(2), 555-569, 2004.

Song, X. and Van Heyst, B.: Volatilization of mercury from soils in response to simulated precipitation, Atmos. Environ., 39(39), 7494-7505, 2005.

Valente, R. J., Shea, C., Lynn Humes, K., and Tanner, R. L.: At- 
mospheric mercury in the Great Smoky Mountains compared to regional and global levels, Atmos. Environ., 41(9), 1861-1873, 2007.

Yatavelli, R. L. N., Fahrni, J. K., Kim, M., Crist, K. C., Vickers, C. D., Winter, S. E., and Connell, D. P.: Mercury, PM2.5 and gaseous co-pollutants in the Ohio River Valley region: Preliminary results from the Athens supersite, Atmos. Environ., 40(34), 6650-6665, 2006.
Zhang, H., Lindberg, S. E., Marsik, F. J., and Keeler, G. J.: Mercury Air/Surface exchange kinetics of background soils of the tahquamenon river watershed in the michigan upper peninsula, Water Air Soil Pollut., 126, 151-169, 2001. 